\title{
PUBLIKASI ILMIAH PUSTAKAWAN: KONTRIBUSINYA PADA CITRA PROFESI, PENGEMBANGAN KARIR DAN TRANSFORMASI ILMU PENGETAHUAN
}

\author{
Achmad Qorni Novianto \\ Pustakawan UPT Perpustakaan Universitas Negeri Malang \\ qorni21@gmail.com
}

\begin{abstract}
ABSTRAK:
Sampai dengan saat ini, produktivitas pustakawan dalam menulis karya ilmiah dapat dikatakan rendah, hal itu dapat dibuktikan dengan belum banyaknya pustakawan yang mempublikasikan karya ilmiahnya (terutama dalam bentuk artikel jurnal/majalah ilmiah dan buku yang diterbitkan secara nasional). Padahal, dalam Permenpan-RB Nomor 9 Tahun 2014, terdapat unsur pengembangan profesi yang merupakan unsur utama kegiatan kepustakawanan dan unsur kegiatan yang mengakomodasi berbagai macam jenis karya ilmiah yang dapat dihasilkan oleh pustakawan. Kegiatan publikasi ilmiah yang dilaksanakan oleh pustakawan mampu berkontribusi terhadap (1) citra profesi pustakawan, (2) pengembangan karir jabatan fungsional pustakawan dan (3) transformasi ilmu pengetahuan bidang kepustakawanan. Kompetensi pustakawan dalam menulis karya ilmiah dapat ditingkatkan melalui (1) metode peer feedback, dan (2) pelatihan menulis karya ilmiah.
\end{abstract}

Kata kunci : pustakawan, publikasi ilmiah

\section{ABSTRACT:}

Until now, the productivity of librarians in writing scientific papers can be said to be low, it can be proven by the fact that not many librarians have published scientific works (especially in the form of scientific journal / magazine articles and books published nationally). In fact, in Permenpan-RB Number 9 of 2014, there are elements of professional development which are the main elements of librarian activities and elements of activities that accommodate various types of scientific work that can be produced by librarians. Scientific publication activities carried out by librarians are able to contribute to (1) the image of the librarian profession, (2) the career development of the librarian functional position and (3) the transformation of librarian science. The competence of librarians in writing scientific papers can be increased through (1) peer feedback methods, and (2) training in writing scientific papers.

Keywords : librarian, scientific publication 


\section{PENDAHULUAN}

Definisi pustakawan dalam UU Nomor 43 Tahun 2007 adalah seseorang yang memiliki kompetensi yang diperoleh melalui pendidikan dan/atau pelatihan bidang kepustakawanan serta memiliki tugas dan tanggungjawab dalam melaksanakan pengelolaan dan pelayanan perpustakaan. ${ }^{1}$ Definisi yang sedikit berbeda mengenai pustakawan terdapat pada Permenpan-RB Nomor 9 Tahun 2014 Pasal 1 ayat 2, yang mendefinisikan pustakawan sebagai Pegawai Negeri Sipil (PNS) yang diberi tugas, tanggung jawab, wewenang dan hak untuk melaksanakan kegiatan kepustakawanan ${ }^{2}$. Meskipun begitu, seseorang yang memiliki kompetensi di bidang kepustakawanan yang bekerja baik di intansi pemerintah maupun swasta layak disebut dengan pustakawan karena telah bekerja dengan penuh dedikasi terhadap dunia perpustakaan dan informasi.

Berdasarkan Permenpan-RB Nomor 9 Tahun 2014, terdapat enam unsur kegiatan jabatan fungsional pustakawan yang dapat dinilai angka kreditnya yang terdiri dari (1) pendidikan, (2) pengelolaan perpustakaan, (3) pelayanan perpustakaan, (4) pengembangan sistem kepustakawanan, (5) pengembangan profesi, dan (6) penunjang tugas pustakawan. Dari 6 unsur kegiatan pustakawan tersebut, terdapat unsur pengembangan profesi yang memuat berbagai macam jenis karya ilmiah yang dapat dihasilkan oleh pustakawan. Bagi pustakawan ahli, kegiatan pengembangan profesi dalam hal ini pembuatan karya tulis ilmiah wajib dilaksanakan sebagai salah satu prasyarat kenaikan jabatan/pangkat pustakawan. Berdasarkan Permenpan-RB Nomor 9 Tahun 2014, yang termasuk kegiatan pengembangan pro-

\footnotetext{
1 Indonesia. Undang-undang Nomor 43 Tahun 2007 Tentang Perpustakaan.

${ }^{2}$ Indonesia. Peraturan Menteri Pendayagunaan Aparatur Negara dan Reformasi Birokrasi RI Nomor 9 Tahun 2014 Tentang Jabatan Fungsional Pustakawan dan Angka Kreditnya.
}

fesi pustakawan adalah (1) pembuatan karya tulis/karya ilmiah di bidang kepustakawanan, (2) penerjemahan/ penyaduran buku dan bahan-bahan lain bidang kepustakawanan; dan (3) penyusunan buku pedoman/ketentuan pelaksanaan/ ketentuan teknis jabatan fungsional pustakawan. Berdasarkan uraian tersebut, diketahui bahwa pustakawan (khususnya pustakawan ahli) harus berpartisipasi dalam pengembangan keilmuan bidang perpustakaan melalui karya tulis ilmiah yang dihasilkan.

Sayyid Quthb dalam (Mursyid, 2015:14) mengatakan "satu peluru hanya dapat menembus satu kepala, tapi satu tulisan dapat menembus ribuan bahkan jutaan kepala". Ungkapan tersebut menunjukkan betapa besar manfaat menulis. Melalui sebuah tulisan, kita dapat memberikan kesempatan pada seseorang untuk berpikir, berimajinasi, dan menggerakkan seseorang untuk bertindak. Dalam dunia akademis, esensi dari kegiatan publikasi karya ilmiah adalah tersedianya karya tulis ilmiah sebagai wahana berbagi informasi dan ilmu pengetahuan. Publikasi ilmiah merupakan salah satu indeks performa bagi para peneliti, akademisi dan ilmuwan, sehingga kita dapat mengetahui kualitas seseorang berdasarkan kualitas tulisannya (Robandi, 2008:148) ${ }^{4}$. Bahkan, di bidang pendidikan tinggi saat ini, jumlah publikasi ilmiah dan jumlah institusi lain yang menga$\mathrm{cu} / \mathrm{mensitir}$ hasil publikasi suatu perguruan tinggi dijadikan sebagai salah satu unsur penilaian akreditasi/pemeringkatan perguruan tinggi. Hal tersebut menunjukkan bahwa publikasi ilmiah mampu berkontribusi dalam meningkatkan reputasi seorang penulis dan lembaga.

Berdasarkan berbagai literatur dan informasi yang telah didapatkan, pengamatan dan pengalaman

\footnotetext{
${ }^{3}$ Mursyid, Moh. Be a Writer Librarian: Strategi Jitu Menjadi Penulis Kreatif Bagi Pustakawan. (Yogyakarta: Ladang Kata, 2015)

${ }^{4}$ Mursyid, Moh. Be a Writer Librarian: Strategi Jitu Menjadi Penulis Kreatif Bagi Pustakawan. (Yogyakarta: Ladang Kata, 2015)
} 
penulis selama menjadi pustakawan, tujuan penulisan artikel ini bertujuan untuk menjelaskan kontribusi publikasi ilmiah pustakawan terhadap (1) citra profesi pustakawan, (2) pengembangan karir jabatan fungsional pustakawan dan (3) transformasi ilmu pengetahuan bidang kepustakawanan. Selain itu, dalam artikel ini akan dibahas strategi pengembangan kompetensi pustakawan dalam menghasilkan publikasi ilmiah yang berkualitas).

\section{TINJAUAN PUSTAKA \\ Definisi, Karakteristik dan Fungsi Karya Tulis Il- miah}

Karya tulis ilmiah menurut Mukhadis (2017:12) merupakan representasi suatu karya keilmuan (pengetahuan ilmiah) melalui lambang, dan/atau symbol dalam bahasa tulis (atau yang lain) yang disusun secara sistematis dengan mengikuti aturan-aturan penulisan ilmiah yang berlaku atau disepakati ${ }^{5}$. Selanjutnya, Indrastuti (2018:2) mengemukakan bahwa karya ilmiah merupakan suatu karya tulis yang berisi analisis suatu hal yang empiris (dapat dibuktikan) dan analisis tentang data nyata yang didasari oleh teori yang relevan dan dilakukan dengan metode atau prosedur ilmiah ${ }^{6}$. Sedangkan menurut Kusmana (2012:4) karya tulis ilmiah adalah karangan yang berisi gagasan ilmiah yang disajikan secara ilmiah serta menggunakan bentuk dan bahasa ilmiah$^{7}$. Berdasarkan definisi karya ilmiah yang dikemukakan oleh para ahli tersebut, dapat disimpulkan bahwa karya ilmiah merupakan karangan yang berisi analisis suatu hal yang bersifat empiris (pengetahuan ilmiah) dan disusun secara sistematis berdasarkan aturan-aturan penulisan ilmiah yang berlaku.

\footnotetext{
${ }^{5}$ Mukhadis, A. Kiat Menulis Karya Ilmiah: Bentuk, Anatomi, Isi Esensial, dan Contoh

Aplikasinya. (Malang: Aditya Media Publishing, 2017)

${ }^{6}$ Indrastuti, Novi. Cara praktis penulisan karya ilmiah dalam Bahasa Indonesia. (Yogyakarta: Gadjah Mada University Press, 2018)

${ }^{7}$ Kusmana, Suherli. Merancang Karya Tulis Ilmiah. (Bandung: Remaja Rosdakarya, 2012)
}

Terdapat beberapa karakteristik suatu karya tulis agar dapat dinyatakan sebagai karya ilmiah. Kusmana mengemukakan karakteristik karya tulis ilmiah sebagai berikut: (1) karya ilmiah menyajikan fakta, yaitu berupa fakta umum yang dapat dibuktikan kebenarannya secara ilmiah; (2) di dalam karangan ilmiah disajikan definisi, metode penyajian definisi sebagai karakteristik karya ilmiah meliputi metode eksplikasi, analisis, deskripsi, ilustrasi, perbandingan, analogi, eliminasi dan etimologi; (3) karangan ilmiah menguraikan permasalahan secara abstrak, jelas/lengkap, objektif, bernalar dan konseptual; (4) menerapkan teori-teori yang dapat dilakukan secara logis, spesifik atau faktual; (5) disajikan pemecahan masalah yang dilakukan dengan cara deduksi, induksi atau berproses.

Menurut Mukhadis (2017:12), suatu karya tulis dikatakan ilmiah jika memiliki kebenaran dari sisi substansi isi secara metodologis dan kemasan paparannya secara umum memiliki kedelapan ciri berikut: (1) menggunakan bahasa prosa, bukan bahasa puisi; (2) menggunakan pola kalimat bentuk lampau; (3) menggunakan pola kalimat bentuk pasif; (4) taat terhadap konvensi; (5) menggunakan format penulisan tertentu; (6) menggunakan bahasa yang benar dan baku; (7) menyajikan persoalan penting; dan (8) disajikan secara sistematis objektif ${ }^{8}$. Selanjutnya, Lasa Hs (2009:290) menyatakan bahwa publikasi ilmiah merupakan publikasi yang memuat informasi mengenai hasil kegiatan dalam bidang ilmu pengetahuan dan teknologi minimal mencakup salah satu dari ketiga aspek yakni: (1) kumpulan/akumulasi pengetahuan baru; (2) pengamatan empiris; dan (3) pengembangan gagasan atau usulan (dimasukkan definisi, karakteristik dsb) ${ }^{9}$. Suyono, dkk (2015:3) mengemukakan bahwa karya ilmiah, baik yang berupa laporan penelitian maupun gagasan kon-

\footnotetext{
${ }^{8}$ Mukhadis, A. Kiat Menulis Karya Ilmiah: Bentuk, Anatomi, Isi Esensial, dan Contoh

Aplikasinya. (Malang: Aditya Media Publishing, 2017)

${ }_{9}$ Lasa Hs. Kamus Kepustakawanan Indonesia. (Yogyakarta: Pustaka Book Publisher, 2009)
} 


\section{Achmad Qorni Novianto}

Publikasi Ilmiah Pustakawan: Kontribusinya pada Citra Profesi,Pengembangan Karir dan Transformasi Ilmu Pengetahuan

septual harus disajikan disertai dengan teori-teori yang relevan ${ }^{10}$. Teori yang relevan berupa konsep-konsep dan prosedur yang relevan (penjelasan yang sistematis yang komprehensif dan tuntas tentang suatu hal/fenomena/entitas oleh pakar di bidangnya berdasarkan penelitian dan/atau gagasan-gagasan ilmiahnya). Teori tersebut dapat menjadi acuan, penguat, atau bahan pembanding dalam suatu karya ilmiah. Berdasarkan pendapat di atas, dapat diketahui bahwa pembuatan suatu karya tulis ilmiah harus didasari oleh teori, konsep dan gagasan yang komprehensif tentang suatu bidang keilmuan.

Terdapat beberapa fungsi publikasi ilmiah sebagaimana dikemukakan oleh Danim, sebagai berikut ${ }^{11}$ :

1. menyuarakan pengetahuan atau pengalaman atau knowledge-telling;

2. mentransformasikan pengetahuan atau knowledge transformational mode;

3. melakukan retorika keilmuan atau rhetorical mode of knowledge, dimana pengetahuan dan pengalaman merupakan representasi dari produksi ekspresi akademik yang berkaitan dengan teks dan substansi temuan atau hasil kerja ilmiah;

4. memecahkan masalah (problem solving) yang relevan dengan bidang pengetahuan dan keilmuan yang menjadi fokus utama kegiatan penelitian atau kajian;

5. sebagai bentuk ekspresi emosional peneliti atas fokus permasalahan yang dihadapinya;

6. sebagai latihan dan proses kognitif seorang pengembang atau ilmuan;

7. menstimulasi diskusi (simulated-recall discussion) sesame pakar sebidang atau antar bidang dalam ke-

\footnotetext{
${ }^{10}$ Suyono, dkk. Cerdas MenulisKarya Ilmiah. (Malang: Gunung Samudera, 2015).

${ }^{11}$ Danim, Sudarwan. Karya Tulis Inovatif:Sebuah Pengembangan Profesi Guru. (Bandung: Remaja Rosdakarya, 2013)
}

rangka pengembangan ilmu, pengetahuan dan teknologi yang relevan; dan

8. mengkreasi, mendiseminasikan dan mengaplikasikan pengetahuan baru, dimana hal itu sangat fundamental bagi terbentuknya khalayak melek informasi.

\section{Publikasi Ilmiah Pustakawan, Kondisi Saat Ini}

Berdasarkan beberapa literatur yang diperoleh penulis, ditemukan fakta bahwa jumlah publikasi ilmiah yang dihasilkan pustakawan masih belum begitu banyak (terutama publikasi secara nasional dalam bentuk buku dan artikel jurnal/majalah ilmiah). Berikut ini terdapat beberapa hasil riset tentang kinerja pustakawan dalam menghasilkan karya ilmiah yang akan dijelaskan sebagai berikut. Berdasarkan riset yang dilakukan oleh Miyanti (2014:85), diperoleh informasi bahwa pada suatu perpustakaan perguruan tinggi negeri yang cukup terkemuka di Indonesia, hanya terdapat dua orang pustakawan yang melakukan penulisan karya ilmiah dari 14 orang pustakawan yang dijadikan responden ${ }^{12}$. Penelitian ini menunjukkan sedikitnya pustakawan yang menulis karya ilmiah, sehingga peneliti hanya mengetahui dua karya ilmiah saja yang mampu dipublikasikan dari 5-8 tulisan yang telah dihasilkan oleh responden.

Selanjutnya, berdasarkan riset yang dilakukan oleh Fitriani dan Yuniwati (2013:2) tentang pengaruh SK Menpan Nomor 132/Kep/M.Pan/12/2002 terhadap produktivitas karya ilmiah pustakawan Universitas Diponegoro pada 36 orang pustakawan, dapat disimpulkan bahwa SK Menpan Nomor 132/KEP/M.Pan/12//2002 tidak berpengaruh terhadap produktivitas karya ilmiah pustakawa ${ }^{13} \mathrm{n}$. Berdasarkan riset tersebut, dapat diketa-

\footnotetext{
${ }^{12}$ Miyanti, T. E. Penulisan karya ilmiah pustakawan Universitas Islam Negeri Syarif Hidayatullah (UIN Syahid) Jakarta. (UIN Syarif Hidayatullah Jakarta. Fakultas Adab dan Humaniora. Jurusan Ilmu perpustakaan. Skripsi, 2014)

${ }^{13}$ Fitriani, L. N., \& Yuniwati, Y. B. Pengaruh SK MENPAN NOMOR 132/KEP/M. PAN/12/2002 Tentang Jabatan Fungsional Pustakawan dan Angka Kreditnya Terhadap Produktivitas Karya
} 
hui bahwa produktivitas karya ilmiah masih belum begitu tinggi. Hal tersebut disebabkan karena dengan atau tanpa membuat karya ilmiah pun pustakawan tetap dapat mengumpulkan angka kredit untuk kenaikan pangkat/jabatan, sehingga pustakawan masih terpaku dengan pekerjaan teknis kepustakawanan. Namun hal ini tidak berlaku bagi pustakawan golongan IV karena untuk kenaikan pangkat harus mengumpulkan angka kredit yang berasal dari unsur pengembangan profesi. Namun, sejak diimplementasikannya permenpan-RB nomor 9 Tahun 2014, pustakawan ahli (dari jabatan pustakawan pertama hingga pustakawan Utama) berkewajiban untuk menghasilkan publikasi ilmiah (unsur kegiatan pengembangan profesi) sebagai prasyarat kenaikan jabatan/pangkat.

Berdasarkan penelitian Novianto (2016:41) di Perpustakaan Universitas Negeri Malang (UM), jenisjenis kegiatan pengembangan profesi yang dilakukan oleh 15 orang pustakawan dalam rentang tahun 20062015 adalah membuat (1) makalah yang disampaikan pada pertemuan ilmiah sebanyak 151 judul (54\%), (2) makalah yang tidak dipublikasikan tetapi didokumentasikan sebanyak 87 judul (31\%), (3) majalah ilmiah sebanyak 21 judul (7\%), (4) buku yang tidak dipublikasikan 8 judul (3\%), (5) buku laporan penelitian 8 judul (3\%),(6) buku yang diterbitkan secara nasional 6judul (2\%), dan (7) membuat buku pedoman di bidang kepustakawanan sebanyak 1 judul $(0,3 \%)^{14}$. Berdasarkan informasi tersebut, dapat diketahui bahwa pustakawan Perpustakaan UM cukup produktif dalam menulis karya ilmiah, meskipun karya tulis yang dipublikasikan secara nasional (baik buku maupun artikel majalah ilmiah/

Ilmiah Pustakawan Universitas Diponegoro. (Jurnal Ilmu Perpustakaan, 2013 2(2), 39-48)

${ }^{14}$ Novianto, Achmad Qorni. Kinerja Pustakawan dalam Melaksanakan Kegiatan Pengembangan Profesi Berdasarkan PermenpanRB Nomor 9 Tahun 2014: Studi Kasus di UPT Perpustakaan Universitas Negeri Malang. (Skripsi, Jurusan Sastra Indonesia, Fakultas Sastra, Universitas Negeri Malang, 2016) jurnal) masih sangat sedikit (buku 6 judul (2\%) dan artikel majalah ilmiah 21 judul (7\%)).

Berdasarkan ketiga penelitian yang telah dijelaskan di atas, dapat diketahui bahwa produktivitas pustakawan dalam menghasilkan karya ilmiah (khususnya buku dan artikel jurnal ilmiah) masih rendah. Terdapat beberapa alasan mengapa belum banyak pustakawan yang memiliki karya tulis ilmiah yang diterbitkan secara nasional, yaitu keterbatasan waktu yang tersedia bagi pustakawan untuk menulis karya ilmiah disela-sela rutinitas kerja dan belum percaya diri terhadap mutu karya ilmiah yang dihasilkan untuk dipublikasikan secara nasional. Hal tersebut sesuai dengan pendapat Novianto (2016:54) yang mengungkapkan alasan pustakawan melaksanakan kegiatan penulisan makalah dan buku yang tidak dipublikasikan dikarenakan waktu untuk menulis terbatas dan seleksi yang cukup ketat yang menyulitkan pustakawan untuk mempublikasikan karya tulis secara nasional ${ }^{15}$. Sebagian besar pustakawan menyatakan bahwa kegiatan penulisan makalah yang tidak dipublikasikan tetapi didokumentasikan dipilih oleh pustakawan karena merupakan kegiatan yang tidak terlalu sulit untuk dilaksanakan dan dapat menghasilkan angka kredit yang cukup besar.

Meskipun sampai dengan saat ini belum banyak karya tulis ilmiah yang dihasilkan pustakawan yang diterbitkan secara nasional, kehadiran karya tulis pustakawan yang didokumentasikan di perpustakaan atau yang dipublish pada web perpustakaan menunjukkan bahwa adanya pustakawan yang merealisasikan ide dan pemikirannya dalam bentuk tulisan. Semangat pustakawan dalam menulis perlu diapresiasi oleh pihak pimpinan dan kedepan dapat diarahkan untuk mengembangkan kompetensinya dalam menulis sehingga dapat mempublikasikan karya tulis ilmiahnya secara nasional

\footnotetext{
${ }^{15}$ Novianto, Achmad Qorni. Kinerja Pustakawan dalam Melaksanakan Kegiatan Pengembangan Profesi Berdasarkan PermenpanRB Nomor 9 Tahun 2014: Studi Kasus di UPT Perpustakaan Universitas Negeri Malang.( Skripsi, Jurusan Sastra Indonesia, Fakultas Sastra, Universitas Negeri Malang, 2016)
} 


\section{Achmad Qorni Novianto}

Publikasi Ilmiah Pustakawan: Kontribusinya pada Citra Profesi,Pengembangan Karir dan Transformasi Ilmu Pengetahuan

atau bahkan internasional. Pelatihan penulisan karya ilmiah bagi pustakawan merupakan salah satu hal yang dapat dipertimbangkan oleh pimpinan perpustakaan untuk mengembangkan kompetensi pustakawan dalam menulis.

Pada saat ini banyak sekali jurnal ilmiah bidang perpustakaan yang dapat dimanfaatkan sebagai wadah publikasi ilmiah pustakawan. Banyak juga bermunculan karya tulis ilmiah pustakawan dalam bentuk kompilasi/bunga rampai yang ditulis oleh beberapa pustakawan. Hal tersebut disebabkan oleh munculnya komunitas pustakawan penulis bidang perpustakaan, salah satunya adalah Kelas Menulis Pustakawan, yaitu komunitas yang diikuti oleh penulis. Hal tersebut membawa pengaruh positif bagi pustakawan agar lebih bersemangat dalam menulis karya ilmiah. Hal tersebut merupakan hal yang sangat positif, berdasarkan pendapat Purwono (2013:124) yang mengemukakan bahwa sebagian besar tenaga pustakawan merupakan pustakawan pekerja, oleh karena itu sudah saatnya komunitas pustakawan Indonesia perlu membentuk pustakawan pemikir dan pustakawan peneliti ${ }^{16}$. Dengan adanya pustakawan pemikir, diharapkan timbulnya dan terealisasinya beberapa pemikiran tentang kepustakawanan Indonesia, sedangkan pustakawan peneliti diharapkan menciptakan produk berupa kajian dan kritik kepustakawanan Indonesia.

\section{METODE PENELITIAN}

Pada penelitian ini, digunakan pendekatan penelitian studi kepustakaan (library research). Jenis penelitan kepustakaan (library research) merupakan penelitian yang berkenaan dengan metode pengumpulan data pustaka yang objek penelitiannya

\footnotetext{
${ }^{16}$ Purwono. Profesi Pustakawan Menghadapi Tantangan Perubahan. (Yogyakarta: Graha Ilmu, 2013)
}

digali melalui beragam informasi kepustakaan (buku, jurnal ilmiah dan hasil penelitian) ${ }^{17}$. Teknik pengumpulan data yang digunakan dalam penelitian ini adalah studi dokumentasi. Data yang digunakan pada penelitian ini adalah data sekunder (data yang diperoleh dari hasil penelitian terdahulu). Sumber data tersebut berupa buku dan jurnal ilmiah yang berkenaan dengan tujuan penelitian. Analisis data dilaksanakan dengan teknik analisis deskriptif dan analisis konten (content analysis) untuk dapat menjelaskan kontribusi publikasi ilmiah bagi pustakawan dan strategi pengembangan kompetensi pustakawan dalam menghasilkan publikasi ilmiah.

\section{HASIL DAN PEMBAHASAN}

Sampai dengan saat ini, produktivitas pustakawan dalam menulis karya ilmiah dapat dikatakan cukup rendah, hal itu dapat dibuktikan dengan belum banyaknya pustakawan yang mempublikasikan karya ilmiahnya (terutama dalam bentuk artikel jurnal/majalah ilmiah dan buku yang diterbitkan secara nasional). Padahal, dalam Permenpan-RB Nomor 9 Tahun 2014, terdapat unsur pengembangan profesi yang merupakan unsur utama kegiatan kepustakawanan dan unsur kegiatan yang mengakomodasi berbagai macam jenis karya ilmiah yang dapat dihasilkan oleh pustakawan.

Berdasarkan analisis data yang telah dilakukan, dapat diketahui bahwa publikasi ilmiah yang dihasilkan pustakawan dapat memberikan hal-hal positif bagi pustakawan. Pertama, publikasi ilmiah pustakawan berkontribusi dalam keilmuan bidang kepustakawanan, karena berbagai pengalaman kerja pustakawan dan ideide pengembangan perpustakaan yang ditulis

\footnotetext{
17 Sukmadinata, Nana Syaodih. Metode Penelitian Pendidikan. (Bandung: Remaja Rosdakarya, 2009)
} 
Almaktabah Vol. 5, No. 1, Juni 2020

pustakawan pada suatu karya ilmiah akan lebih bermanfaat jika dipublikasikan secara luas. Kedua, publikasi ilmiah pustakawan berkontribusi dalam meningkatkan citra profesi pustakawan, karena menulis karya ilmiah merupakan salah satu upaya pemasaran kepada publik mengenai berbagai hal yang terkait dalam sebuah profesi. Ketiga, publikasi ilmiah pustakawan berkontribusi dalam pengembangan karir jabatan fungsional pustakawan, karena dalam Permenpan-RB Nomor 9 Tahun 2014, kegiatan penulisan karya ilmiah dapat dilaksanakan oleh semua jenjang jabatan pustakawan dan angka kreditnya cukup besar. Penjelasan secara komprehensif tentang kontribusi publikasi ilmiah bagi pustakawan diuraikan sebagai berikut.

\section{Kontribusi Publikasi Ilmiah Dalam Transformasi Ilmu Pengetahuan Bidang Kepustakawanan}

Jika dicermati, dalam Al-Qur'an surat Al-Alaq, sebenarnya Allah SWT tidak hanya memerintahkan manusia untuk membaca (iqra') sebagaimana yang sering dijadikan dasar gerakan membaca, tetapi juga perintah untuk menulis. Pada ayat keempat, Allah SWT juga memerintahkan untuk menulis, "yang mengajar (manusia) dengan perantara qalam (pena/tulisan)" (Mursyid, 2015:9) ${ }^{18}$. Berdasarkan risalah tersebut, sangat jelas bahwa Islam mengajak agar manusia, dalam hal ini juga pustakawan untuk selalu membaca dan menulis. Ayat tersebut sekaligus mengajarkan kepada kita bahwa kegiatan menulis merupakan proses transformasi pengetahuan.

Suyono, dkk (2015:9) berpendapat bahwa kegiatan menulis bertujuan untuk menyampaikan ide atau pemikiran yang didasari oleh penalaran logis serta dapat diverifikasi kebenaran isinya. Selanjutnya, Kuntarto dan Putranto (2015:1) berpendapat bahwa apabila tidak menulis dan memublikasikan karya ilmiah, seorang aka-

\footnotetext{
${ }^{18}$ Mursyid, Moh. Be a Writer Librarian: Strategi Jitu Menjadi Penulis Kreatif Bagi Pustakawan. (Yogyakarta: Ladang Kata, 2015)
}

demisi akan punah: publish or perish ${ }^{19}$. Melalui publikasi ilmiah, berbagai karya penulis akan bermanfaat bagi kualitas hidup manusia dan sebagai sarana pembuktian serta eksistensi penulis pada suatu bidang profesi. Berdasarkan pendapat-pendapat tersebut, dapat diketahui bahwa dalam bidang perpustakaan dan informasi, kontribusi pustakawan dalam menulis karya ilmiah bidang perpustakaan dapat digunakan sebagai sarana pembuktian eksistensi pustakawan sebagai suatu profesi atau bidang kelimuan.

Karya tulis ilmiah selalu mengusung permasalahan tentang suatu bidang keilmuan. Materi yang dituangkan dalam tulisan ilmiah berupa gagasan-gagasan ilmiah, baik berupa hasil kajian ilmiah maupun hasilhasil penelitian yang disajikan dalam karya tulis ilmiah. Gagasan-gagasan tersebut merupakan gambaran perkembangan ilmu pengetahuan yang terekam dalam tulisan ilmiah (Kusmana, 2012:4) ${ }^{20}$. Berikut ini akan dijelaskan siklus perkembangan ilmu pengetahuan.

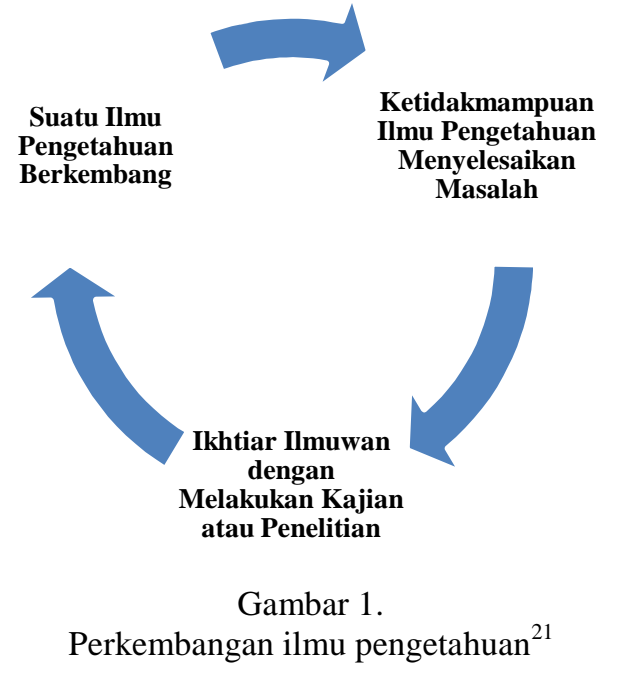

Berdasarkan siklus tersebut, dapat diketahui bahwa pengetahuan ilmiah pada hakikatnya senantiasa berkembang dari waktu ke waktu. Hal itu disebabkan

\footnotetext{
${ }^{19}$ Kuntarto, Niknik M. \&Putranto, Hendar. 99 Cara Mudah Menulis Karya Ilmiah. (Yogyakarta: Indopublika, 2015)

${ }^{20}$ Kusmana, Suherli. Merancang Karya Tulis Ilmiah. (Bandung: Remaja Rosdakarya, 2012)

${ }^{21}$ Kusmana, Suherli. Merancang Karya Tulis Ilmiah. (Bandung: Remaja Rosdakarya, 2012.)
} 
perkembangan ilmu pengetahuan sejalan dengan perkembangan manusia memecahkan permasalahan hidupnya dan merumuskan paradigma baru yang tertuang dalam karya tulis ilmiah. Publikasi ilmiah berkaitan erat dengan istilah komunikasi ilmiah. American Library Association (ALA) mendifinisikan komunikasi ilmiah sebagai sebuah sistem dimana hasil riset dan tulisantulisan ilmiah lainnya dibuat, dievaluasi dari segi kualitas, disebarluaskan kepada masyarakat ilmiah, dan diabadikan untuk penggunaan masa depan ${ }^{22}$. Berikut ini adalah siklus komunikasi ilmiah yang terdiri dari penelitian, penulisan, publikasi dan diseminasi, demikian seterusnya.

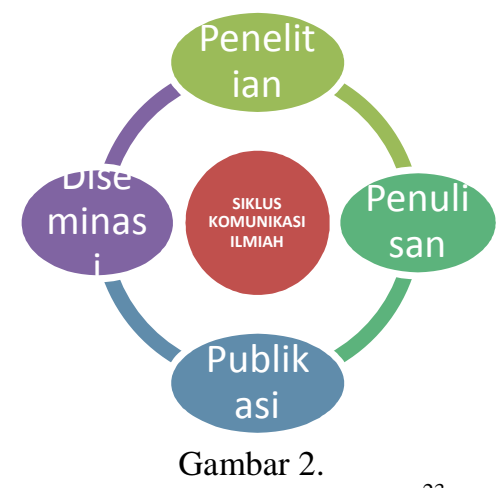

Siklus Komunikasi Ilmiah $^{23}$

Berdasarkan siklus komunikasi ilmiah diatas, dapat diketahui bahwa pustakawan dapat berkontribusi pada seluruh aspek yang ada dalam siklus komunikasi ilmiah. Jika selama ini pustakawan telah berperan sebagai partner peneliti, mempublikasikan dan mendiseminasikan berbagai konten karya ilmiah, pustakawan berhak untuk berpartisipasi dalam pengembangan keilmuan bidang perpustakaan. Berbagai pengalaman kerja

${ }^{22}$ ACRL Scholarly Communications Committee. Priciple and Strategies for the Reform of Scholarly Communication 1. Tersedia di http://www.ala.org/acrl/publications/ whitepapers/ principlesstrategies diakses 3 Februari 2020.

${ }^{23}$ Istiana, Purwani. Peran Luas Pustakawan dalamMendukung Visibilitas Publikasi Institusi Berkelanjutan. (Media Pustakawan, 2017 24(3), 1-8.) dan peluang-peluang pengembangan perpustakaan dan kepustakawanan yang dimiliki dapat diukir menjadi karya tulis ilmiah yang tentu akan berkontribusi pada pengembangan keilmuan bidang perpustakaan.

Berbagai pengalaman kerja pustakawan maupun ide-ide pengembangan perpustakaan yang ditulis pada suatu karya ilmiah akan lebih bermanfaat jika dipublikasikan secara luas, misalnya dalam bentuk buku maupun jurnal/majalah ilmiah. Dapat dibayangkan jika suatu tulisan/makalah yang sangat berkualitas yang dihasilkan oleh pustakawan hanya didokumentasikan di perpustakaan saja tanapa dipublikasikan secara luas, hal itu akan sangat disayangkan karena bisa jadi tulisan tersebut mampu menginspirasi penulis-penulis lain untuk menghasilkan karya-karya baru di bidang perpustakaan. Hal tersebut sesuai dengan pendapat Danim (2013:18) yang mengemukakan bahwa temuan-temuan penelitian akan mati atau hanya sebatas "harta karun" jika tidak dipublikasika ${ }^{24}$. Selanjutnya, Danim (2013:19) juga menyebutkan bahwa mestinya, para peneliti dan pengabdi terpanggil untuk mempublikasikan hasil penelitian atau pengabdian mereka dalam bentuk buku atau artikel di jurnal. Hal tersebut dilakukan pustakawan agar hasil penelitiannya dapat bermanfaat dan diketahui oleh masyarakat luas. Selain itu, bukan tidak mungkin melalui tulisan yang kita hasilkan akan membantu mahasiswa, pustakawan, dosen maupun pemerhati bidang perpustakaan dalam mengembangkan ide dan gagasan di bidang ilmu perpustakaan yang berdampak pada kemajuan bidang ilmu perpustakaan.

\section{Kontribusi Publikasi Ilmiah pada Pengembangan Citra Profesi Pustakawan}

Profesi pustakawan bagi sebagian besar masyarakat Indonesia masih dianggap profesi kelas dua, pen-

\footnotetext{
${ }^{24}$ Danim, Sudarwan. Karya Tulis Inovatif: Sebuah Pengembangan Profesi Guru. (Bandung: Remaja Rosdakarya, 2013)
} 
jaga perpustakaan, profesi buangan dan berbagai hal negatif lainnya. Hapsari (2015:95) menuturkan penyebab profesi pustakawan belum dilirik oleh masyarakat, yaitu pustakawan seringkali terjebak dengan rutinitas pekerjaan seperti sirkulasi, mengolah buku dan sejenisnya, sehingga sulit menghilangkan stigma pustakawan adalah penjaga buku di perpustakaan ${ }^{25}$. Selanjutnya, Hapsari (2015:95) mengemukakan bahwa peningkatan citra profesi pustakawan baru dapat bertahan dan bersaing dengan pekerjaan/profesi sejenis jika pustakawan memiliki nilai tambah, diantaranya memiliki kemampuan bahasa asing, kemampuan teknologi informasi untuk menelusur sumber-sumber informasi, kemampuan berkomunikasi dan kemampuan menulis. Berdasarkan pendapat tersebut, kemampuan menulis karya ilmiah diyakini dapat meningkatkan citra profesi pustakawan yang sampai dengan saat ini masih dipandang sebelah mata oleh masyarakat.

Keyakinan penulis bahwa dengan banyaknya publikasi ilmiah pustakawan dapat meningkatkan citra profesi pustakawan, sesuai dengan pendapat Mursyid (2015:10) yang menyatakan bahwa dengan menulis, pustakawan dapat mempengaruhi pikiran masyarakat atau opini publik ${ }^{26}$. Selain itu, dengan menulis pustakawan dapat menjadi pelopor aksi gerakan visible librarian, yaitu pustakawan yang nampak di mata masyarakat. Hal ini tentu akan menepis stigma negatif yang selama ini disimpulkan masyarakat tentang profesi pustakawan sebagai penjaga buku. Bahkan, berdasarkan pengalaman pribadi penulis sebagai pustakawan, penulis pernah dianggap hanya lulusan SMA oleh beberapa pemustaka karena mereka sering melihat penulis dan pustakawan lainnya mengelola jajaran koleksi (shelving). Hal itu tentu menjadi sebuah ironi, mengingat sampai dengan saat ini banyak sekali bermunculan pro-

\footnotetext{
${ }^{25}$ Hapsari, Dian dkk. Membangun Citra Positif Pustakawan di Era persaingan Bebas. (Yogyakarta: Ladang Kata, 2015)

${ }^{26}$ Mursyid, Moh. Be a Writer Librarian: Strategi Jitu Menjadi Penulis Kreatif Bagi Pustakawan. (Yogyakarta: Ladang Kata, 2015)
}

gram studi ilmu perpustakaan pada berbagai universitas di Indonesia yang tentu berimbas pada tersedianya tenaga kompeten pengelola perpustakaan.

Unsur kegiatan pengembangan profesi tidak hanya dapat memfasilitasi pustakawan untuk mencapai target pengumpulan angka kredit kenaikan pangkat/golongan semata, namun juga berfungsi dalam meningkatkan citra profesi pustakawan melalui penulisan karya ilmiah oleh pustakawan (Novianto, 2016:3) ${ }^{27}$. Menulis karya tulis ilmiah merupakan salah satu upaya pemasaran kepada publik mengenai berbagai hal yang terkait dalam sebuah profesi. Berdasarkan penjelasan tersebut, dapat diketahui bahwa produktivitas pustakawan dalam melaksanakan penulisan karya ilmiah sebagaimana diatur dalam unsur kegiatan pengembangan profesi Permenpan-RB Nomor 9 tahun 2014 diperlukan dalam upaya meningkatkan citra profesi pustakawan. Seseorang yang menduduki jabatan fungsional pustakawan seharusnya tidak hanya melaksanakan kegiatan pelayanan teknis dan pelayanan pemustaka saja, namun juga melaksanakan penulisan karyai lmiah dalam bidang perpustakaan.

Kontribusi pustakawan dalam komunikasi ilmiah bidang perpustakaan dan informasi merupakan salah satu langkah pembuktian eksistensi pustakawan dan upaya meningkatkan profesionalisme profesi pustakawan. Hal tersebut sesuai pendapat Darmono (2007:16) yang menyatakan bahwa komunikasi ilmiah merupakan salah satu cara untuk meningkatkan profesionalisme pustakawan $^{28}$. Oleh karena itu, majalah ilmiah atau popular dan jurnal bidang perpustakaan perlu dikembangkan untuk menunjang terciptanya atmosfir yang kondusif dalam pengembangan profesionalisme pusta-

\footnotetext{
${ }^{27}$ Novianto, Achmad Qorni. Kinerja Pustakawan dalam Melaksanakan Kegiatan Pengembangan Profesi Berdasarkan PermenpanRB Nomor 9 Tahun 2014: Studi Kasus di UPT Perpustakaan Universitas Negeri Malang. (Skripsi, Jurusan Sastra Indonesia, Fakultas Sastra, Universitas Negeri Malang, 2016)

${ }^{28}$ Darmono. Peningkatan Citra dan Pengembangan Profesionalisme Pustakawan: Oleh Pustakawan dan UntukPustakawan. (Media Pustakawan Vol. 14 No.3 dan 4 Desember 2007 hal.9-18.)
} 
Achmad Qorni Novianto

Publikasi Ilmiah Pustakawan: Kontribusinya pada Citra Profesi,Pengembangan Karir dan Transformasi Ilmu Pengetahuan

kawan. Kondisi riil yang kita hadapi adalah pustakawan kita kurang produktif dalam menulis. Komunikasi ilmiah melalui media tulisan secara tidak langsung dapat meningkatkan citra profesi.

Hardiningtyas mengemukakan bahwa pustakawan akan mampu menyejarahkan dirinya sebagai seorang pustakawan professional melalui karya tulisnya ${ }^{29}$. Membangun branding pustakawan dapat dilakukan melalui berbagai aktivitas dibidang kepenulisan. Karya tulis yang dipublikasikan atau bahkan hanya didokumentasikan di perpustakaan atau instansi yang bersangkutan, akan terus menjadi prasasti dirinya, bahwa seorang pustakawan penulis pernah hadir dan berkarya. Itulah hasil karya seorang pustakawan yang akan berguna bagi generasi mendatang. Pendapat tersebut menunjukkan bahwa eksistensi pustakawan akan dapat terukir dalam sejarah melalui publikasi ilmiah yang dihasilkan.

\section{Kontribusi Publikasi Ilmiah Pada Pengembangan Karir Pustakawan}

Di era globalisasi yang sarat akan perubahan ini, menurut (Noh, 2011:213) pustakawan harus mampu mengembangkan karirnya dengan terus belajar dan mengelola karir mereka secara proaktif ${ }^{30}$. Keberhasilan pustakawan dalam karirnya (mengejar jenjang jabatan/pangkat dan golongannya) akan sangat tergantung pada keberhasilannya melaksanakan berbagai tugas seperti yang tercakup dalam unsur-unsur dan sub-sub unsur kegiatan pustakawan yang dapat dinilai angka kreditnya sesuai dengan tingkat dan jenjang jabatannya (Sutino, 2013:22) ${ }^{31}$. Unsur kegiatan kepustakawanan

${ }^{29}$ Hardiningtyas, Tri. Karya Pustakawan Kekinian. (Surakarta: Yuma Pustaka, 2018)

${ }^{30}$ Noh, Y. A study on the conceptualization of librarians' career movement and identification of antecedents. (Journal of Librarianship and Information Science, 2011 43(4), 213-223)

${ }^{31}$ Sutino. Jenjang Jabatan, Motivasi dan Prestasi Kerja Pustakawan: Studi Kasus pada Pustakawan Penyelia di Perpustakaan Univer- yang dapat dinilai angka kreditnya sesuai Pasal 4 Permenpan-RB Nomor 9 Tahun 2014 Tentang Jabatan Fungsional Pustakawan dan Angka Kreditnya adalah (1) pendidikan, (2) pengelolaan perpustakaan, (3) pelayanan perpustakaan, (4) pengembangan sistem kepustakawanan, (5) pengembanganprofesi, dan (6) penunjang tugas pustakawan ${ }^{32}$. Dalam hal ini, keberhasilan pustakawan dalam pengembangan karirnya ditentukan pada keberhasilannya dalam melaksanakan tugasnya yang didasarkan pada unsur kegiatan pustakawan dalam Permenpan-RB Nomor 9 Tahun 2014.

Berdasarkan Permenpan-RB Nomor 9 tahun 2014 Pasal 13, kegiatan pengembangan profesi merupakan unsur utama kegiatan pustakawan. Namun, dalam riset yang dilakukan oleh Andriaty dan Hendrawati (2013:27), pengembangan profesi termasuk di dalamnya penyusunan karya tulis ilmiah (KTI) merupakan kegiatan utama pustakawan, namun belum banyak pustakawan yang mengajukan KTI yang diterbitkan dalam jurnal atau media lainnya, padahal kegiatan ini mempunyai nilai angka kredit yang lebih besar dibandingkan dengan pekerjaan teknis ${ }^{33}$. Hal ini tentu saja amat disayangkan karena dengan nilai angka kredit yang lebih besar, akan memudahkan pustakawan dalam mencapai target perolehan angka kredit yang ditetapkan untuk mengusulkan kenaikan pangkat/jabatan. Berdasarkan Permenpan-RB Nomor 9 Tahun 2014 Pasal 15 diwajibkan pelaksanaan kegiatan pengembangan profesi kepada pustakawan tingkat ahli. Pustakawan tingkat ahli diwajibkan melaksanakan kegiatan pengembangan profesi setiap kenaikan golongan/jabatan sejak menduduki jabatan Pustakawan Pertama Golongan III/b sampai

sitas Gadjah Mada dan Universitas Negeri Yogyakarta. (Jurnal FKP2T, 20114 (1):22-32.)

32 Indonesia. Permenpan-RB RI Nomor 9 Tahun 2014 Tentang Jabatan Fungsional Pustakawan dan Angka Kreditnya.

${ }^{33}$ Andriaty, Etty \& Hendrawaty. Kajian Penilaian Angka Kredit PustakawanLingkup Kementrian Pertanian. (Jurnal Perpustakaan Pertanian Vol. 22 No. 1 April 2013: 24-29). 
Almaktabah Vol. 5, No. 1, Juni 2020

dengan jabatan Pustakawan Utama Golongan IV/e. Setiap kenaikan jabatan/golongan pustakawan yang lebih tinggi mempersyaratkan pengumpulan angka kredit dari kegiatan pengembangan profesi yang lebih besar, sehingga pustakawan yang bersangkutan harus dapat me- menuhi persyaratan tersebut sebagai prasyarat kenaikan jabatan/pangkat pustakawan.

Ketentuan mengenai kewajiban pelaksanaan kegiatan pengembangan profesi bagi pustakawan ahli telah diatur berdasarkan Permenpan-RB Nomor 9 Tahun 2014 Pasal 15 yang dijelaskan pada tabel berikut.

Tabel 1.

Jenjang Jabatan / Golongan Pustakawan Tingkat Ahli dan Kebutuhan Angka Kredit dalam Kegiatan Pengembangan Profesi

\begin{tabular}{cllc}
\hline No. & Jabatan/Golongan & \multicolumn{1}{c}{ Kenaikan Jabatan/Golongan } & $\begin{array}{c}\text { Angka Kredit Pen- } \\
\text { gembangan Profesi }\end{array}$ \\
\hline 1 & Pustakawan Pertama / III/b & Pustakawan Muda / III/c & 2 \\
\hline 2 & Pustakawan Muda / III/c & Pustakawan Muda / III/d & 4 \\
\hline 3 & Pustakawan Muda / III/d & Pustakawan Madya / IV/a & 6 \\
\hline 4 & Pustakawan Madya/ IV/a & Pustakawan Madya / IV/b & 8 \\
\hline 5 & Pustakawan Madya / IV/b & Pustakawan Madya / IV/c & 10 \\
\hline 6 & Pustakawan Madya / IV/c & Pustakawan Utama / IV/d & 12 \\
\hline 7 & Pustakawan Utama / IV/d & Pustakawan Utama / IV/e & 14 \\
\hline
\end{tabular}

Pada tabel tersebut, dapat diketahui bahwa setiap kenaikan pangkat dan jabatan pustakawan ahli dipersyaratkan angka kredit pengembangan profesi yang lebih besar seiring dengan semakin tingginya pangkat dan jabatan pustakawan ahli. Meskipun hanya diwajibkan pada pustakawan ahli, pustakawan jenjang terampil juga diperbolehkan melaksanakan kegiatan pengembangan profesi. Berdasarkan riset Novianto (2019:131) dapat diketahi bahwa terdapat juga pustakawan tingkat terampil yang melaksanakan kegiatan pengembangan profesi meskipun dalam Permenpan-RB Nomor 9 Tahun 2014 mereka tidak diwajibkan untuk melaksanakan kegiatan pengembangan profesi ${ }^{34}$. Salah satu hal yang mendasari pelaksanaan kegiatan pengembangan profesi adalah angka kredit yang cukup besar yang dapat berkontribusi dalam kenaikan jabatan/pangkat pustakawan.

Terdapat perbedaan butir-butir kegiatan unsur pengembangan profesi pustakawan pada Kepmenpan

\footnotetext{
34 Novianto, Achmad Qorni. Analisis Sebaran Butir Kegiatan Pustakawan Berdasarkan Permenpan-RB Nomor 9 Tahun 2014. (Baca: Jurnal Dokumentasi Dan Informasi, 201940 (1), 123135.)
}

Nomor 132/KEP/M.PAN/12/2002 dengan PermenpanRB Nomor 9 Tahun 2014, salah satunya adalah kegiatan menjalankan tugas sebagai Ketua Kelompok Pustakawan merupakan bagian dari kegiatan pengembangan profesi pada Kepmenpan Nomor 132/KEP/M.PAN/12/2002, namun kegiatan tersebut tidak diakui pada Permenpan-RB Nomor 9 Tahun 2014. Berikut ini perbedaan dari kedua peraturan tersebut sehubungan dengan butir-butir kegiatan pengembangan profesi pustakawan. 
Tabel 2.

Perbandingan Kegiatan Pengembangan Profesi Pustakawan

\begin{tabular}{|c|c|}
\hline \multicolumn{2}{|c|}{ Kegiatan Pengembangan Profesi Jabatan Fungsional Pustakawan } \\
\hline Kepmenpan Nomor 132/KEP/M.PAN/12/2002 & Permenpan-RB Nomor 9 Tahun 2014 \\
\hline $\begin{array}{l}\text { 1. Membuat karya tulis/karya ilmiah di bidang per- } \\
\text { pustakaan, dokumentasi dan informasi }\end{array}$ & $\begin{array}{l}\text { 1. Pembuatan karya tulis/karya ilmiah di bidang kepusta- } \\
\text { kawanan. }\end{array}$ \\
\hline $\begin{array}{l}\text { 2. Menyusun pedoman/petunjuk teknis perpstakaan, } \\
\text { dokumentasi dan informasi }\end{array}$ & $\begin{array}{l}\text { 2. Penerjemahan/penyaduran buku dan bahan-bahan lain } \\
\text { bidang kepustakawanan. }\end{array}$ \\
\hline $\begin{array}{l}\text { 3. Menerjemahkan/menyadur buku dan bahan-bahan } \\
\text { lain di bidang perpstakaan, dokumentasi dan in- } \\
\text { formasi }\end{array}$ & $\begin{array}{l}\text { 3. Penyusunan buku pedoman/ketentuan pelaksa- } \\
\text { naan/ketentuan teknis jabatan fungsional pustakawan. }\end{array}$ \\
\hline $\begin{array}{l}\text { 4. Melakukan tugas sebagai ketua kelom- } \\
\text { pok/koordinator pustakawan atau memimpin unit } \\
\text { perpustakaan }\end{array}$ & \\
\hline 5. Menyusun kumpulan tulisan untuk dipublikasikan & \\
\hline $\begin{array}{l}\text { 6. Memberi konsultasi kepustakawanan yang bersifat } \\
\text { konsep }\end{array}$ & \\
\hline
\end{tabular}

Dengan bergulirnya Permenpan-RB Nomor 9 Tahun 2014, seorang pustakawan ahli harus menghasilkan karya tulis ilmiah untuk dapat memperoleh angka kredit hasil kegiatan pengembangan profesi. Berbeda dengan Kepmenpan Nomor 132/KEP/M.PAN/12/2002 yang memungkinkan seorang pustakawan mendapatkan angka kredit dari kegiatan melakukan tugas sebagai koordinator pustakawan atau memimpin unit perpustakaan. Hal itu menjadi tantangan tersendiri bagi pustakawan untuk dapat menulis dan ikut berkontribusi dalam pengembangan keilmuan dan transformasi ilmu pengetahuan, meskipun tujuan utamanya adalah sebagai prasyarat kenaikan jabatan/pangkat.

Pelaksanaan kegiatan pengembangan profesi dapat memberikan kontribusi yang cukup signifikan dalam pengembangan karir pustakawan. Berdasarkan lampiran I dan II Permenpan-RB Nomor 9 Tahun 2014, dapat diketahui bahwa angka kredit kegiatan pengembangan profesi cukup besar. Selain itu, butir-butir kegiatan pengembangan profesi tidak mempersyaratkan pelaksananya pada jenjang jabatan tertentu saja. Semua jenjang jabatan pustakawan, baik pustakawan ahli (Pustakawan Pertama, Pustakawan
Muda, Pustakawan Madya dan Pustakawan Utama) maupun pustakawan terampil (Pustakawan Pelaksana, Pustakawan Pelaksana Lanjutan dan Pustakawan Penyelia) diperbolehkan melaksanakan kegiatan pengembangan profesi tanpa terkecuali. Hal itu berbeda dengan butir-butir kegiatan unsur pelayanan perpustakaan (baik layanan teknis dan layanan pemustaka) yang mempersyaratkan jenjang jabatan tertentu sebagai pelaksana kegiatan. Hal tersebut cukup menguntungkan bagi pustakawan untuk dapat mengumpulkan angka kredit kenaikan jabatan/pangkat, karena tidak jarang terdapat pustakawan yang kesulitan mencari angka kredit dari kegiatan sehari-hari dikarenakan tempat ia bertugas tidak mampu mengakomodir butir-butir kegiatan dalam Permenpan-RB Nomor 9 Tahun 2014 sesuai jenjang jabatannya.

\section{Mengembangkan Kompetensi Pustakawan Dalam Menulis Karya Ilmiah}

Menulis merupakan salah satu dari empat keterampilan berbahasa yang mendasar (berbicara, mendengar, menulis dan berbicara). Khususnya menulis, latihan merupakan kunci yang paling utama demi mencapai kesuksesan untuk mencapai kesuksesan untuk mencapai predikat mampu menulis dengan baik dan benar (Zai 
nurrahman, 2013:2) $)^{35}$. Pada dasarnya, kegiatan membaca dan menulis merupakan hal yang tidak terpisahkan. Menulis adalah mempraktikkan hasil dari membaca ke dalam sebuah tulisan untuk dikomunikasikan kepada orang lain. Untuk dapat menulis dan mengarang dengan baik, seseorang harus menjadi "pengamat" terlebih dahulu, dalam arti memperhatikan dan mempelajari gaya penulisan seseorang yang sudah berpengalaman menulis (Mursyid, 2015:24) ${ }^{36}$. Dengan semakin sering membaca dan berlatih untuk menulis, tentu karya tulis yang akan dihasilkan akan semakin berkualitas.

Dengan beragam rutinitas pekerjaan di perpustakaan, pustakawan perlu mengoptimalkan waktu yang tersedia untuk menulis karya ilmiah dengan optimal. Rutinitas kerja yang demikian padat dijadikan alasan utama bagi pustakawan untuk tidak menulis. Hal itu tentu berbeda dengan pendapat Zainurrahman (2011:220) yang menyatakan bahwa kesibukan hendaknya dapat dioptimalkan menjadi sarana untuk menemukan bahan-bahan baru untuk dikemukakan dalam tulisan kita ${ }^{37}$. Oleh karena itu, pustakawan dapat mengoptimalkan kesibukan kerjanya untuk menjadi bahan penulisan dikala terdapat waktu untuk menulis. Pustakawan hendaknya dapat memahami ritme pekerjaan di perpustakaan (misal di bagian layanan) dimana ada kalanya ramai dan sepi pengunjung. Ketika sepi pengunjung, pustakawan dapat memanfaatkan waktu yang tersedia untuk banyak membaca referensi dan mulai menulis berbagai topik/permasalahan yang ingin kita tuangkan dalam tulisan.

${ }^{35}$ Zainurrahman. Menulis: dari teori hingga praktik (penawar racun plagiarisme). (Bandung: Alfabeta, 2013)

${ }^{36}$ Mursyid, Moh. Be a Writer Librarian: Strategi Jitu Menjadi Penulis Kreatif Bagi Pustakawan. (Yogyakarta: Ladang Kata, 2015)

${ }^{37}$ Zainurrahman. Menulis: dari teori hingga praktik (penawar racun plagiarisme). (Bandung: Alfabeta, 2013)
Terdapat strategi mengembangkan kompetensi pustakawan dalam menulis karya ilmiah yang berkualitas adalah sebagai berikut.

Pertama, menggunakan metode peer feedback. Secara terminologis, peer feedback artinya seorang penulis memberikan dan mendapatkan kritikan, masukan, dorongan dari penulis lain yang berperan sebagai pembaca (Zainurrahman, 2013:188) ${ }^{38}$. Dalam hal ini, para pustakawan yang sudah menghasilkan karya ilmiah saling memberikan masukan terhadap karya tulis yang dihasilkan. Hal tersebut secara tidak langsung akan meningkatkan kualitas karya ilmiah yang dihasilkan, karena pada intinya karya ilmiah yang telah ditulis ditujukan untuk dibaca orang lain. Diantara beberapa keuntungan yang didapatkan dengan implementasi metode peer feedback adalah penulis dan pembaca bukan hanya sekedar berbagai pengetahuan dan pengalaman mengenai bagaimana menulis yang baik dan benar, tetapi juga sinkronisasi pemahaman sosial yang memungkinkan terjadinya korelasi sosial yang signifikan dan positif antar partisipan dalam peer feedback.

Kedua, pelatihan menulis karya ilmiah, agar pustakawan dapat mengetahui konsep dasar dan strategi menulis. Hal tersebut sesuai dengan pendapat Novianto (2016:87) yang menuturkan bahwa melalui kegiatan pelatihan penulisan karya ilmiah, diharapkan dapat memacu keinginan menulis, meningkatkan kompetensi dan produktivitas kerja pustakawan dalam menulis karya ilmiah $^{39}$. Sebaiknya, perpustakaan secara rutin menyelenggarakan atau mengikutsertakan pustakawan pada pelatihan penulisan karya ilmiah. Pelatihan penulisan karya ilmiah tidak hanya diperlukan bagi pustakawan yang belum kompeten dalam menulis, tetapi dapat

${ }^{38}$ Zainurrahman. Menulis: dari teori hingga praktik (penawar racun plagiarisme). (Bandung: Alfabeta, 2013)

${ }^{39}$ Novianto, Achmad Qorni. 2016. Kinerja Pustakawan dalam Melaksanakan Kegiatan Pengembangan Profesi Berdasarkan Permenpan-RB Nomor 9 Tahun 2014: Studi Kasus di UPT Perpustakaan Universitas Negeri Malang. Skripsi. 
digunakan untuk penyegaran konsep penulisan bagi pustakawan yang sudah mahir menulis.

\section{KESIMPULAN DAN SARAN}

Dari segi kemanfaatannya bagi pustakawan, publikasi ilmiah pustakawan berkontribusi dalam (1) transformasi ilmu pengetahuan bidang kepustakawanan; (2) meningkatkan citra profesi pustakawan, dan (3) pengembangan karir jabatan fungsional pustakawan.

Perkembangan ilmu pengetahuan berjalan secara beriringan dengan perkembangan manusia memecahkan permasalahan hidupnya serta merumuskan paradigma baru yang tertuang dalam karya tulis ilmiah. Sebagai praktisi di bidang perpustakaan dan informasi, pustakawan dapat berperan pada berbagai aspek pada siklus komunikasi ilmiah (penelitian-penulisan-publikasidiseminasi dst). Berbagai pengalaman kerja pustakawan dan ide/gagasan pengembangan perpustakaan yang ditulis pada suatu karya ilmiah akan lebih bermanfaat jika dipublikasikan secara luas. Dengan mempublikasikan buah pemikiran pustakawan dalam suatu karya tulis ilmiah, bukan tidak mungkin karya tulis tersebut tersebut mampu menginspirasi penulis-penulis lain untuk menghasilkan karya-karya baru yang berdampak pada kemajuan bidang ilmu perpustakaan.

Menulis karya tulis ilmiah merupakan salah satu upaya pemasaran kepada publik mengenai berbagai hal yang terkait dalam sebuah profesi, tak terkecuali pustakawan. Dengan menulis karya ilmiah yang dipublikasikan secara luas melalui buku, artikel jurnal ilmiah maupun media massa, pustakawan dapat mempengaruhi dan menepis opini masyarakat yang masih memandang sebelah mata profesi pustakawan. Kontribusi pustakawan dalam komunikasi ilmiah bidang perpustakaan dan informasi merupakan salah satu langkah pembuktian ek- sistensi pustakawan dan upaya meningkatkan profesionalisme profesi pustakawan dalam dunia akademik.

Pelaksanaan kegiatan pengembangan profesi, dalam hal ini penulisan karya ilmiah dapat memberikan kontribusi yang cukup signifikan dalam pengembangan karir pustakawan. Terdapat beberapa keuntungan bagi pustakawan ketika melaksanakan kegiatan pengembangan profesi, yaitu (1) angka kredit kegiatan pengembangan profesi cukup besar, dan (2) butir-butir kegiatan pengembangan profesi dapat dilaksanakan oleh semua jenjang jabatan pustakawan. Kegiatan pengembangan profesi dapat membantu pustakawan dalam mengumpulkan angka kredit untuk kenaikan jabatan/pangkat, karena tidak jarang terjadi pustakawan yang kesulitan mencari angka kredit dari kegiatan sehari-hari dikarenakan tempat ia bertugas tidak mampu mengakomodir butir-butir kegiatan dalam Permenpan-RB Nomor 9 Tahun 2014 sesuai jenjang jabatannya.

Kegiatan menulis karya ilmiah harus senantiasa dilatih, karena diperlukan latihan dan banyak pengalaman untuk menghasilkan karya tulis yang berkualitas. Selain itu, pustakawan harus dapat mengoptimalkan waktu yang terbatas disela-sela rutinitas pekerjaan di perpustakaan untuk menulis karya ilmiah. Terdapat strategi mengembangkan kompetensi pustakawan dalam menulis karya ilmiah yang berkualitas (1) menggunakan metode peer feedback, para pustakawan yang sudah menghasilkan karya ilmiah saling memberikan masukan terhadap karya tulis yang dihasilkan, dan (2) pelatihan menulis karya ilmiah, kegiatan ini tidak hanya diperlukan bagi pustakawan yang belum kompeten dalam menulis, tetapi juga dalam rangka penyegaran konsep penulisan bagi pustakawan yang sudah mahir menulis. 
Almaktabah Vol. 5, No. 1, Juni 2020

\section{DAFTAR PUSTAKA}

ACRL Scholarly Communications Committee. Priciple and Strategies for the Reform of Scholarly Communication 1. Tersedia di http://www.ala.org/acrl/publications/ whitepapers/principlesstrategies diakses 3 Februari 2020.

Andriaty, Etty \& Hendrawaty. 2013. Kajian Penilaian Angka Kredit PustakawanLingkup Kementrian Pertanian. JurnalPerpustakaanPertanian Vol. 22 No. 1 April 2013: 24-29. (Online) (http://ejurnal.litbang.pertanian.go.id/index.ph p/jpp/article/view/2361) diaksespada18Juni 2019.

Darmono. 2007. Peningkatan Citra dan Pengembangan Profesionalisme Pustakawan: Oleh Pustakawan dan UntukPustakawan. Media Pustakawan Vol. 14 No.3 dan 4 Desember 2007 hal.9-18.

Danim, Sudarwan. 2013. Karya Tulis Inovatif: Sebuah Pengembangan Profesi Guru. Bandung: Remaja Rosdakarya

Fitriani, L. N., \& Yuniwati, Y. B. 2013. Pengaruh SK MENPAN NOMOR 132/KEP/M.

PAN/12/2002 Tentang Jabatan Fungsional Pustakawan dan Angka Kreditnya Terhadap Produktivitas Karya Ilmiah Pustakawan Universitas Diponegoro. Jurnal Ilmu Perpustakaan, 2(2), 39-48.

Hapsari, Dian dkk. 2015. Membangun Citra Positif Pustakawan di Era persaingan Bebas. Yogyakarta: Ladang Kata.

Hardiningtyas, Tri. 2018. Karya Pustakawan Kekinian. Surakarta: Yuma Pustaka

Indonesia. Undang-undang Nomor 43 Tahun 2007 Tentang Perpustakaan.

Indonesia. Peraturan Menteri Pendayagunaan Aparatur Negara dan Reformasi Birokrasi RI Nomor 9 Tahun 2014 Tentang Jabatan Fungsional Pustakawan dan Angka Kreditnya.

Indrastuti, Novi. 2018. Cara praktis penulisan karya ilmiah dalam Bahasa Indonesia. Yogyakarta: Gadjah Mada University Press.

Istiana, Purwani. 2017. Peran Luas Pustakawan dalam Mendukung Visibilitas Publikasi Institusi Berkelanjutan. Media Pustakawan, 24(3), 1-8.
Kuntarto, Niknik M. \&Putranto, Hendar. 2015. 99 Cara Mudah Menulis Karya Ilmiah. Yogyakarta: Indopublika

Kusmana, Suherli. 2012. Merancang Karya Tulis Ilmiah. Bandung: Remaja Rosdakarya

Lasa Hs. 2009. Kamus Kepustakawanan Indonesia. Yogyakarta: Pustaka Book Publisher.

Miyanti, T. E. 2014. Penulisan karya ilmiah pustakawan Universitas Islam Negeri Syarif Hidayatullah (UIN Syahid) Jakarta. UIN Syarif Hidayatullah Jakarta. Fakultas Adab dan Humaniora. Jurusan Ilmu perpustakaan. Skripsi.

Mukhadis, A. 2017. Kiat Menulis Karya Ilmiah: Bentuk, Anatomi, Isi Esensial, dan Contoh Aplikasinya. Malang: Aditya Media Publishing.

Mursyid, Moh. 2015. Be a Writer Librarian: Strategi Jitu Menjadi Penulis Kreatif Bagi Pustakawan. Yogyakarta: Ladang Kata

Noh, Y. 2011. A study on the conceptualization of librarians' career movement and identification of antecedents. Journal of Librarianship and Information Science, 43(4), 213-223.

Novianto, Achmad Qorni. 2016. Kinerja Pustakawan dalam Melaksanakan Kegiatan Pengembangan Profesi Berdasarkan Permenpan-RB Nomor 9 Tahun 2014: Studi Kasus di UPT Perpustakaan Universitas Negeri Malang. Skripsi, Jurusan Sastra Indonesia, Fakultas Sastra, Universitas Negeri Malang

Novianto, Achmad Qorni. 2019. Analisis Sebaran Butir Kegiatan Pustakawan Berdasarkan PermenpanRB Nomor 9 Tahun 2014. Baca: Jurnal Dokumentasi Dan Informasi, 40 (1), 123-135.

Purwono. 2013. Profesi Pustakawan Menghadapi Tantangan Perubahan. Yogyakarta: Graha Ilmu.

Robandi, Imam. 2008. Becoming the winner: riset, menulis ilmiah, publikasi ilmiah dan Presentasi. Yogyakarta: Andi.

Sukmadinata, Nana Syaodih. 2009. Metode Penelitian Pendidikan. Bandung: Remaja Rosdakarya. 
Achmad Qorni Novianto

Publikasi Ilmiah Pustakawan: Kontribusinya pada Citra Profesi,Pengembangan Karir dan

Transformasi Ilmu Pengetahuan

Sutino. 2011. Jenjang Jabatan, Motivasi dan Prestasi Kerja Pustakawan: Studi Kasus pada Pustakawan Penyelia di Perpustakaan Universitas Gadjah Mada dan Universitas Negeri Yogyakarta. Jurnal FKP2T, 4 (1):22-32.

Suyono, dkk. 2015. Cerdas MenulisKarya Ilmiah. Malang: Gunung Samudera

Zainurrahman. 2013. Menulis: dari teori hingga praktik (penawar racun plagiarisme). Bandung: Alfabeta 